\title{
Correction to: Manoeuvrability in adverse conditions: rational criteria and standards
}

\author{
Vladimir Shigunov ${ }^{1}[$
}

Published online: 26 February 2018

(c) The Author(s) 2018. This article is an open access publication

\section{Correction to: Journal of Marine Science and Technology https://doi.org/10.1007/s00773-017-0525-z}

The article Manoeuvrability in adverse conditions: rational criteria and standards, written by Vladimir Shigunov, was originally published electronically on the publisher's internet portal (currently SpringerLink) on 15 January 2018 without open access.

With the society's decision to grant Open Choice the copyright of the article changed on 20 February 2018 to $($ ) The Author(s) 2018 and the article is forthwith distributed under the terms of the Creative Commons Attribution 4.0 International License (http://creativecommons.org/licenses/ by/4.0/), which permits use, duplication, adaptation, distribution and reproduction in any medium or format, as long as you give appropriate credit to the original author(s) and the source, provide a link to the Creative Commons license and indicate if changes were made. The original article was corrected.

Open Access This article is distributed under the terms of the Creative Commons Attribution 4.0 International License (http://creativeco mmons.org/licenses/by/4.0/), which permits unrestricted use, distribution, and reproduction in any medium, provided you give appropriate credit to the original author(s) and the source, provide a link to the Creative Commons license, and indicate if changes were made.
The original article can be found online at https://doi.org/10.1007/ s00773-017-0525-z.

Vladimir Shigunov

VLADIMIR.SHIGUNOV@dnvgl.com

1 DNV GL SE, Hamburg, Germany 